Original Research Paper

\title{
Impact of Financial Globalization on Banking Risks
}

\author{
${ }^{1}$ Larisa Yuzvovich, ${ }^{1}$ Elena Knyazeva, ${ }^{1}$ Natalia Mokeeva, \\ ${ }^{1}$ Elena Avramenko and ${ }^{2}$ Maksim Maramygin \\ ${ }^{I}$ Ural Federal University, Ekaterinburg, Russia \\ ${ }^{2}$ Ural State Economic University, Ekaterinburg, Russia
}

Article history

Received: 28-12-2015

Revised: 28-03-2016

Accepted: 18-04-2016

Corresponding Author:

Larisa Yuzvovich

Ural Federal University,

Ekaterinburg, Russia

Email: yuzvovich@bk.ru

\begin{abstract}
Financial globalization definitely has an overall effect on globalization in the banking sector. This is reflected in averaging of banking risks for all parties, which occurs due to the impact of the markets, economies, private corporations and monopolies as well as states on each other. As a result, just the opposite priorities in monetary policy may have the same beneficial effect. The aim of the study is to develop conceptual scientific and methodological research areas concerning diversification of banking risks in the context of financial globalization. As part of a comprehensive analysis of the resulting indicators of financial and economic activities of the Russian banking sector, the authors have assessed the key financial performance of the major lending institutions of the Russian banking system in order to identify the dependence of the Russian banking sector on external factors. Financial globalization in general, of course, affects the globalization in the banking sector in particular. This is reflected in averaging banking risks for all parties to the process as a result of the integrative impact of markets, economies, private corporations and monopolies. In this study the authors have presented the mechanism of integrative motion of economic processes with regard to the financial globalization impact on the results of the countries' monetary policy. Development of market relations and rapid financial globalization lead to permanent transformations of risks that require new approaches and methods of management.
\end{abstract}

Keywords: Financial Globalization, Banking Risks, Integration

\section{Introduction}

The priority document of the global banking community-Core Principles for Effective Banking Supervision-defines the following banking risks: Credit risk, country and transfer risk, market risk, interest rate risk, liquidity risk, operational risk, legal risk and reputation risk. At the present time, from our perspective, most obvious risks in the banking business are credit, interest rate, liquidity and inflation risks.

In Russia, like in many other countries, credit risk is the main and most significant one in the total of all risks assumed by credit institutions. In the post-crisis years we saw a rapid recovery of credit investments and as a result- the increasing credit risk in the banking sector.

Experts' concern about this issue-diversification of banking risks in financial globalization-should be appropriately reflected in scientific and applied research, revealing the theoretical and methodological aspects of risk management.
A significant contribution to the creation of the domestic theory of risk management in the banking activities, to the scientific study of the nature of risks and content of risk methodology was made by Russian scholars (Beloglazova and Krolivetskaya, 2010; Vishnyakov and Radaev, 2008; Dimitriadi, 2010; Zharikov et al., 2009; Tepman and Eriashvili, 2013). The theoretical justification for risk systematization is presented in the works of Russian and foreign scientists and economists (Granaturov, 2010; Lavrushin, 2014; Shapkin and Shapkin, 2013; Sheremet and Shcherbakova, 2001; Sharpe et al., 2011; Vine, 2013; Norman, 2013; Keynes, 2012; Rose, 1995).

Problems of methodology development for risk management in the banking activities are addressed in the works of the leading representatives of the scientific community (Belyakov, 2004; Volkov, 2014; Madera, 2014; Molyneux, 2011; Murphy, 2012). Issues of the conceptual apparatus, the essence of banking risks are raised in the works (Irishev, 2014; Krichevsky, 2013; 
Olsevich, 2014; Shapkin and Shapkin, 2013; Van Greuning and Bratanovic, 2007; Vine, 2013).

To illustrate the relevance of the theme, we should highlight the following. Economic consequences of ininflation risks are considered from perspectives, different in their interpretation of the inflation impact on the economic growth. It has been estimated that the threshold inflation at which a considerable increase in prices significantly slows down the growth for industrialized countries amounts to $1-3 \%$, for developing ones $7-10 \%$, for countries with transitional economies it is $50 \%$. One may assume that this point of view has not been confirmed empirically, but in industrialized countries the inflation of up to $5 \%$ per year is accompanied by the economic upturn. The growth is slowing down parallel to the rise of inflation, capital is overflowing from production to trade, commission business and to the financial markets, where capital turnover is faster, profits are bigger and where it is easier to evade taxation. Finally, increasing economic imbalances, decreasing investments, absence of incentives for crediting accompanied with a further rise in inflation could lead the economy into stagflation.

The impact of inflation on accumulation is represented through changes in the structure of accumulation and the reduction of its real volume. Decrease in the real monetary capital and its negative yield lead to depreciation of accumulated part of the national income. Savings are decreasing along with higher inflation, which enables financing of the current consumption. Investors are saving their money by buying foreign currency, high-yield securities, tangible assets (real estate, gold, antiques, etc.). The savings structure is changing, stocks and materials start playing a more important role. Negative savings are accompanied with decreasing investments, which, in turn, leads to ageing of fixed assets and cost escalation, increasing inflation.

The impact of inflation on crediting creates a situation when, due to high inflation, loans become unprofitable for a credit grantor and profitable for a credited party, which leads to changes in the credit structure and limits credit operations. Rising prices first reduce the number of long-term and then of mediumterm loans, since inflation makes long-term loans unprofitable not only at fixed, but often even at a floating rate that depends on the market situation.

The impact of inflation on the balance of payments shows itself through a reduction in export and an increase in import. Higher prices mean domestic currency depreciation and, as a result, weakening competitiveness of export products. Due to this, inflation stimulates the growth of the export deficit and threatens the balance of payments.

As for anti-inflationary measures, monetary policy of the state and central banks is mentioned most frequently. This policy is aimed at assisting the economy to achieve the overall production, characterized by full employment and price stability. It implies changes in the money supply aimed at stabilization of the overall production, employment and prices. Implementing monetary policy, the Central Bank influences lending activities of commercial banks and regulates the situation either expanding or reducing business loans to ensure a stable development of the domestic economy, improved money supply and the equilibrium of internal economic processes. Thus, controlling credits allows for overall more flexible strategic development of the economy. In this regard, we should also mention the strengths and weaknesses of the methods of monetary regulation when operating the economy as a whole. The following arguments speak in favor of monetary policy. Firstly, it is quicker and more flexible than fiscal policies. It is known that fiscal policy may be delayed because of approval legislative procedures which may take a long while. However, it is different for monetary policy. The Central Bank may take decisions concerning buying or selling of assets daily, thus regulating the money supply and the interest rate. Secondly, in developed countries this policy is not a subject to political pressure; moreover, it is inherently softer than fiscal policy and can operate more accurately; therefore it seems to be more acceptable on the political plane.

The findings enable more efficient functioning of the Russian banking sector and deepen the theoretical and methodological basis for the development of more effective mechanisms aimed at diversification of banking risks.

Scientific and practical ideas have been applied by OJSC Bank "Otkrytie", Moscow and OJSC "VUZ-Bank", Yekaterinburg, as well as taken into consideration by the management of OJSC "Gazprombank", Yekaterinburg. They were also used for solving certain practical problems, aimed at a comprehensive and systemic improvement of management and risk diversification of banking risks in the context of financial globalization. The findings are used at the Boris Yeltsin Ural Federal University (Yekaterinburg) and the Ural State Economic University (Yekaterinburg).

Theoretical and methodological basis of the research is: The fundamental provisions of economic and financial sciences with both classical and modern understanding of the central theoretical and practical points of risk diversification in the banking sector; monographic scientific publications devoted to regularities in foreign and national risk management systems; creating software and recommendations for banking professionals. Methodological apparatus of the research embraces methods of system and structural analysis, factor and comparative analysis, constructing analytical and integrative models based on the synthesis of modern scientific approaches to studying economic 
and social phenomena. The research is carried out with the application of the following methods of information processing: Historical, logical, graphical, statistical, economic and mathematical.

\section{Materials and Method}

Resources and empirical basis of the research are: Federal laws and regulations of the Russian Federation and its subjects concerning the issues of risk management, banks and banking industry performance; official statistical data of the Federal State Statistics Service; analytical materials of the Central Bank of the Russian Federation; proceedings of scientific conferences; experts reports in periodicals; reference materials and electronic information systems; consolidated financial statements of the banking sector and individual banks. The data base is representative enough; therefore, there is a solid basis for creating a complete picture for comprehensive assessment of the impact of financial globalization on banking risks.

Dear-money policy, if carried out actively enough, can definitely reduce the reserves of commercial banks to the point at which the banks are forced to restrict loans. The following means limiting the money supply in the economy. Another negative factor is that velocity of money circulation tends to change inversely to the money supply, thus slowing down and eliminating changes in the money supply carried out by the regulator.

Despite the fact that monetary policy of each country is implemented independently, financial globalization influences it in such a way that different economies demonstrate integration trends aimed at achieving the common goal. Let us consider the mechanism of this influence (Fig. 1).

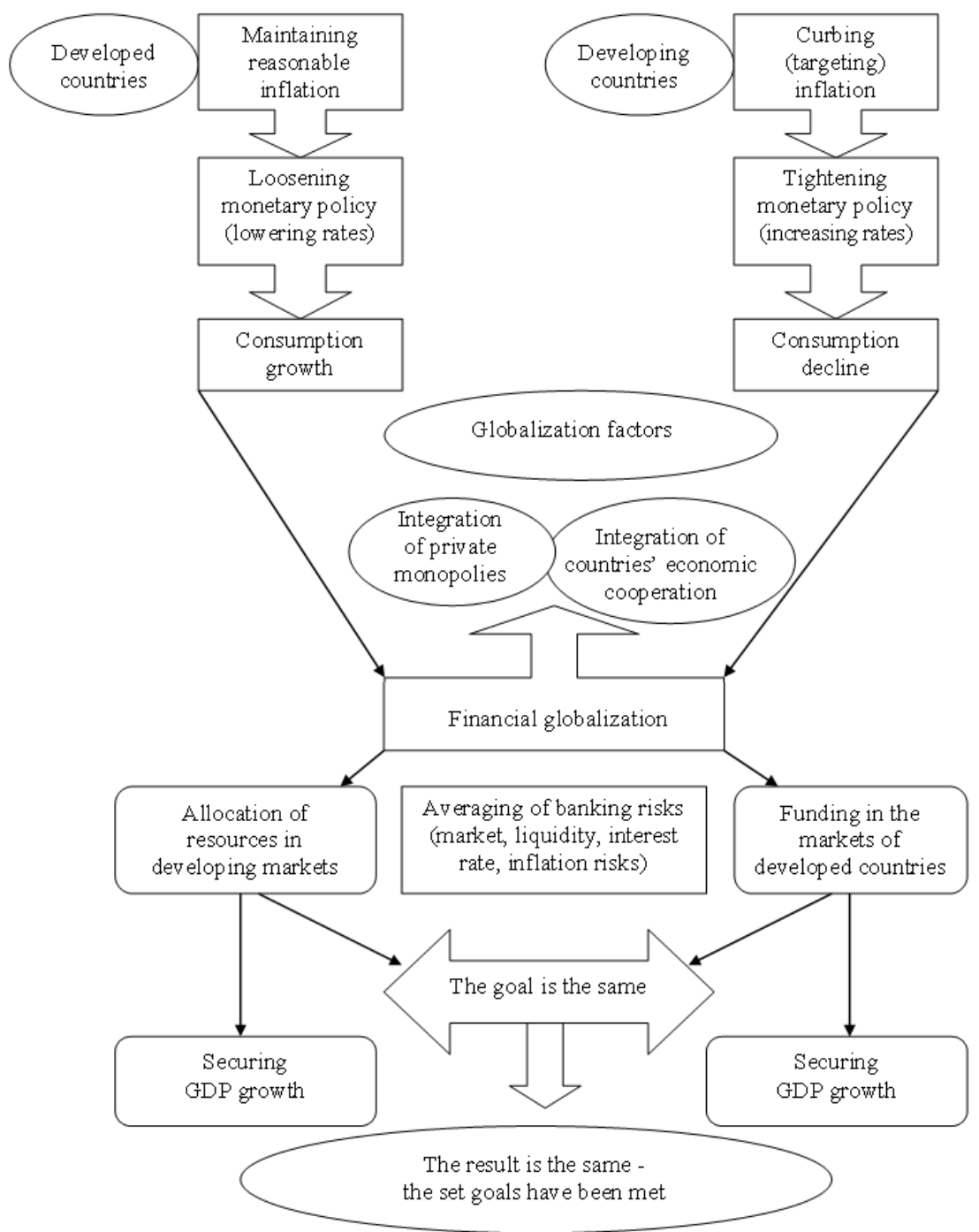

Fig. 1. Mechanism of integrative economic processes in the context of the financial globalization impact on the outcomes of the countries' monetary policy 


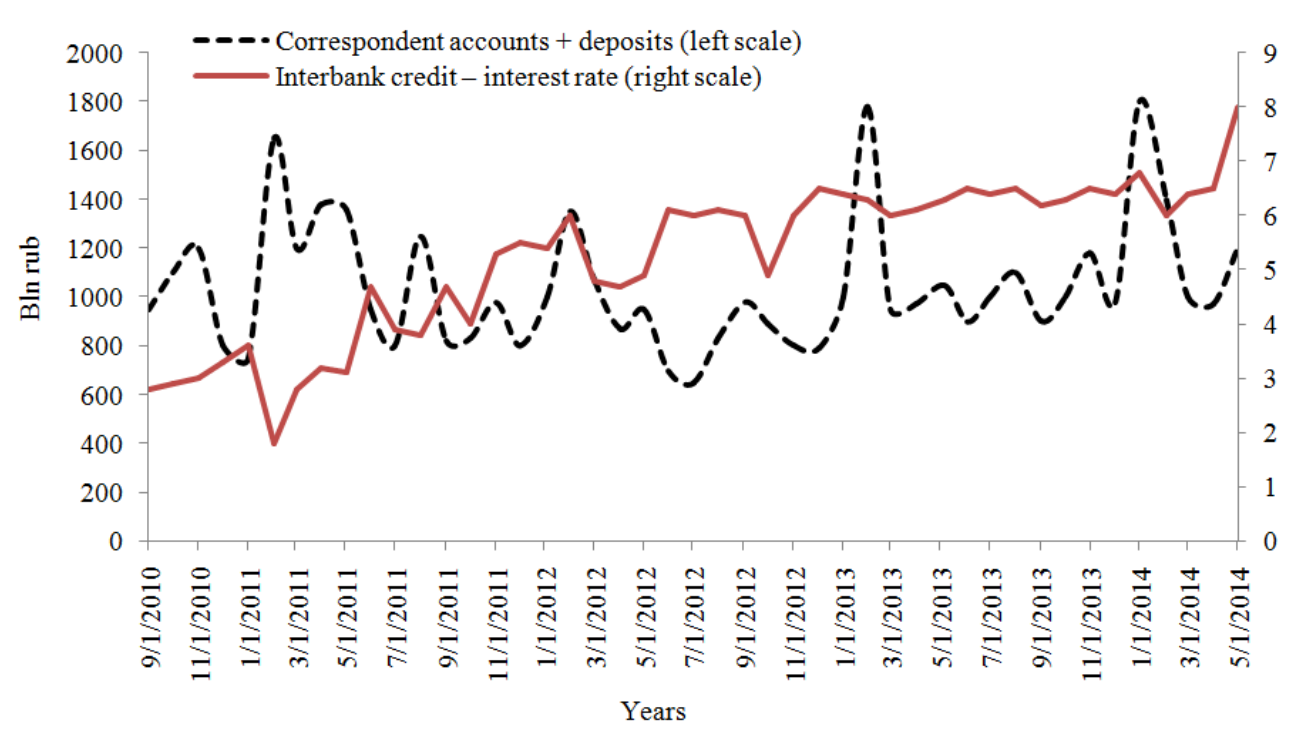

Fig. 2. Correlation of Russia's banking system liquidity and the cost of funding; Source: OMM (2014)

That is, though the increasing influence of financial globalization results in a growing number of risks in the banking sector, they are averaged and diversified. Russia's membership in international organizations and ratification of the agreements enables to facilitate competition in all markets, including the banking.

Russian banking market is closely linked to the global market. It responds to all processes- no matter positive or negative, - going on other markets. Monetary authorities constantly monitor trends and risks of both the global and domestic market. At the beginning of 2014 the ruble liquidity of Russia's banking sector reached its maximum value for the previous year. Prior to that, similar figures had been observed in Q1 of 2013 as a result of Cyprus crisis and the flight of capital from this offshore jurisdiction. In Q1 of 2014 the increase in the liquidity position occurred due to Ukrainian crisis and introduction of sanctions against Russia by Western countries. However, after reaching its peak, it began to go down quite rapidly. Decrease in the liquidity base for the first quarter of 2014 from 1.8 to 1 trillion rubles in early March; that was followed by tightening of monetary policy and the key rate increasing from 5.5 to $7.5 \%$. As a result, average money market rates on overnight loans rose by $2 \%$ compared to the beginning of 2014 (Fig. 2).

The Central Bank is trying to allay these fears, assuring the players in the market that there will be no liquidity deficit or its consequence- an increased demand for repos with the Central Bank of Russia (CBR).

However, since the beginning of 2014 debts of the banking sector on transactions with the Central Bank increased by $30 \%$ from RUB 3.9 thsd to RUB 5.1 thsd. In the situation of limited market collateral, CBR loans remained a valuable source of liquidity in the considered period, the loans secured by non-marketable assets, which were significantly stimulated by the Bank of Russia's introduction of monthly credit auctions for a period of 3 months.

\section{Results}

In the context of ongoing high demand of the banking sector for refinancing, increasing of the security market enables to mitigate the collateral deficit. In this regard, emissions on the debt security market appear to be the most important issue: Bonds traditionally constitute a main part in the portfolios of Russian lending organizations.

High volatility of financial markets and rising interest rates in the beginning of 2014 made flotation of bonds less attractive. Due to this, issuing volumes on the domestic bond market in Q1 of 2014 turned out to be comparatively low. The volume of initial placements of both corporate bonds and federal loan bonds in Q1 of 2014 was lower than in each of the quarters of 2013. On the domestic market, the total issuing volume was less than RUB 0.3 thsd. The flotation value of Eurobond was also slightly lower than the average in 2013. In future, this collateral deficit can exacerbate the situation with debt refunding. In general, due to sanctions and a further sharp decline in funding volumes on Western capital markets, participants both of the banking and corporate sectors had to borrow those sums from the Central Bank.

From our perspective, net liquidity position provides the most accurate estimate, which reflects the reserves of free ruble funds in the banking system. The net liquidity position is calculated as the difference between the amount of liquid assets (correspondent accounts, the Central Bank deposits and the Bank of Russia bonds) 
and the total amount of banks liabilities to the Central Bank. Along with the net liquidity position, we use the ratio of liquid assets to the liabilities which credit institutions have to the Central Bank (liquidity ratio) to assess the solvency of the system. Within these methods of analysis, the level of bank liquidity is considered to be sufficient only when the net liquidity position is greater than zero or the liquidity ratio is greater than one. The excess liquidity is registered when the net liquidity position exceeds the residues on correspondent accounts and deposits in the Central Bank. The author supports the position of the Central Bank that the existing liquidity problems are of "non-systematic nature".

Further reduction of ruble liquidity is dangerous as it leads to increasing dependency of the banks on borrowing (including foreign) and in this way increases its vulnerability.

The structural shortage of liquidity and the Bank of Russia operations on liquidity support/absorption are shown in Fig. 3.

As a consequence, in addition to traditional sources of funding (interbank loans, inter-dealer repo and repo with the Central Bank), loans from the Ministry of Finance at the deposit auctions have become more popular. In fact, though this cannot be interpreted as an extreme liquidity deficit, the situation in the money and bond market is already quite difficult and can lead to a further increase in interbank rates. According to the "Main directions of the Russian Federation debt management policy for 2013-2015" approved by the Ministry of Finance in 2012, the Ministry of Finance plans to cover about $70 \%$ of deficit budget by means of domestic borrowing. The federal budget deficit in 2014, 2015 and 2016 is expected to amount to RUB 389.6 bln, RUB 796.6 bln and RUB486.5 bln, respectively. It is assumed that deficit financing will require about RUB 500 bln of public borrowing annually. The market of federal loan bonds, according to the CBR, amounted to RUB 3.735 thsd as of January 1, 2014.

According to the document on debt policy management, in 2014 the government is planning to call for $11.2 \%$ less than in 2013 in the domestic market-about RUB 400 bln (including repayments); in 2015-23.1\% less than in 2014 about RUB 306 bln. It seems that in the coming years the government plans for borrowing will operate with smaller numbers. But the government interests are still likely to be largely determined by the budget needs, rather than optimizing the borrowing costs.

In the current situation with liquidity, we believe that at least in the next year there will be no exponential growth in the segment of local government debt unless there appears a new high-quality group of investors or foreign investors return to the Russian market. By January 1, 2014 the share of non-residents at the federal loan bond market amounted to $23.9 \%$-RUB $894 \mathrm{bln}$. As can be seen from Fig. 4, foreign investors mainly prefer bonds with maturity between 3 and 10 years.

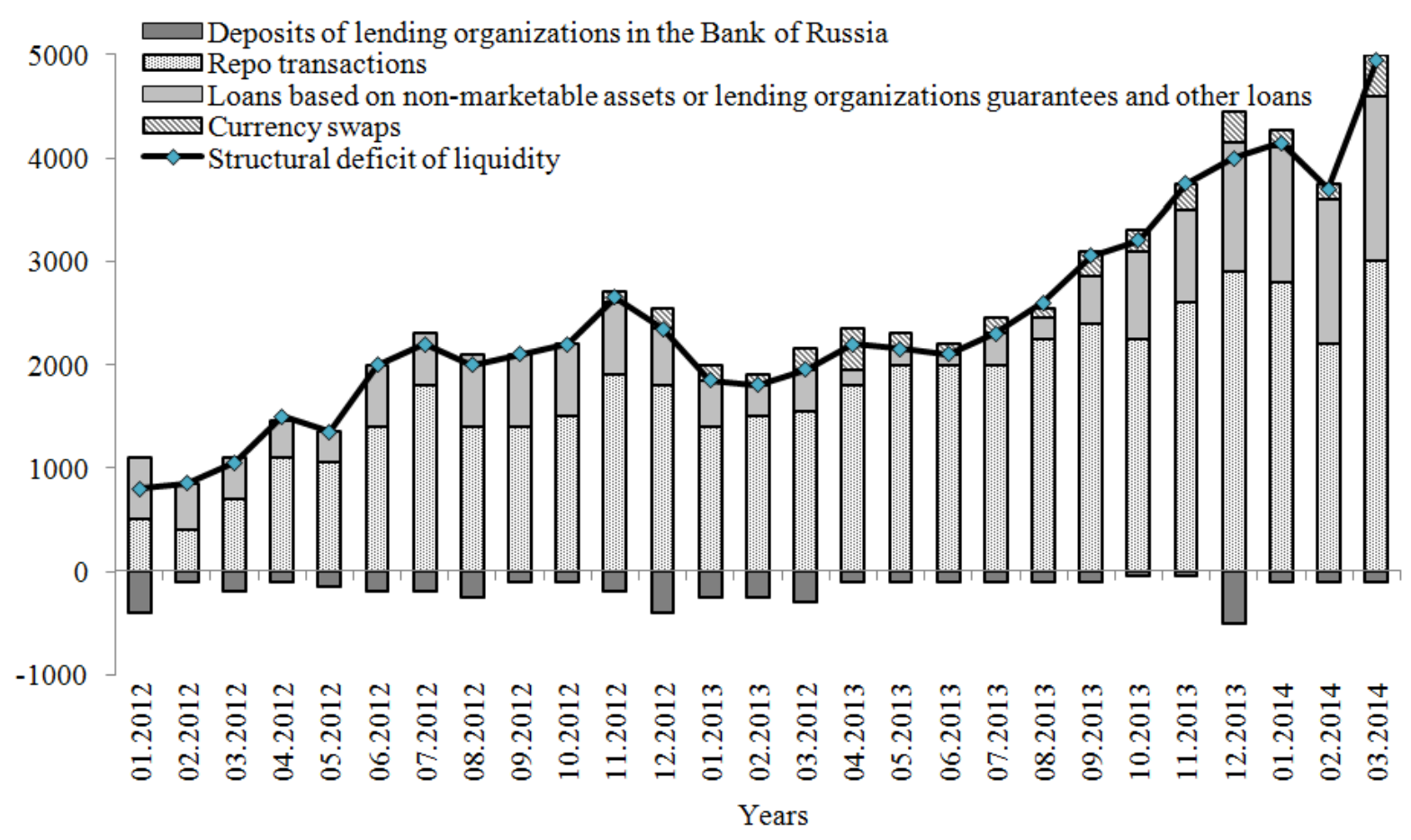

Fig. 3. The structural deficit of liquidity and the Bank of Russia operations on liquidity support/absorption, bln rub 


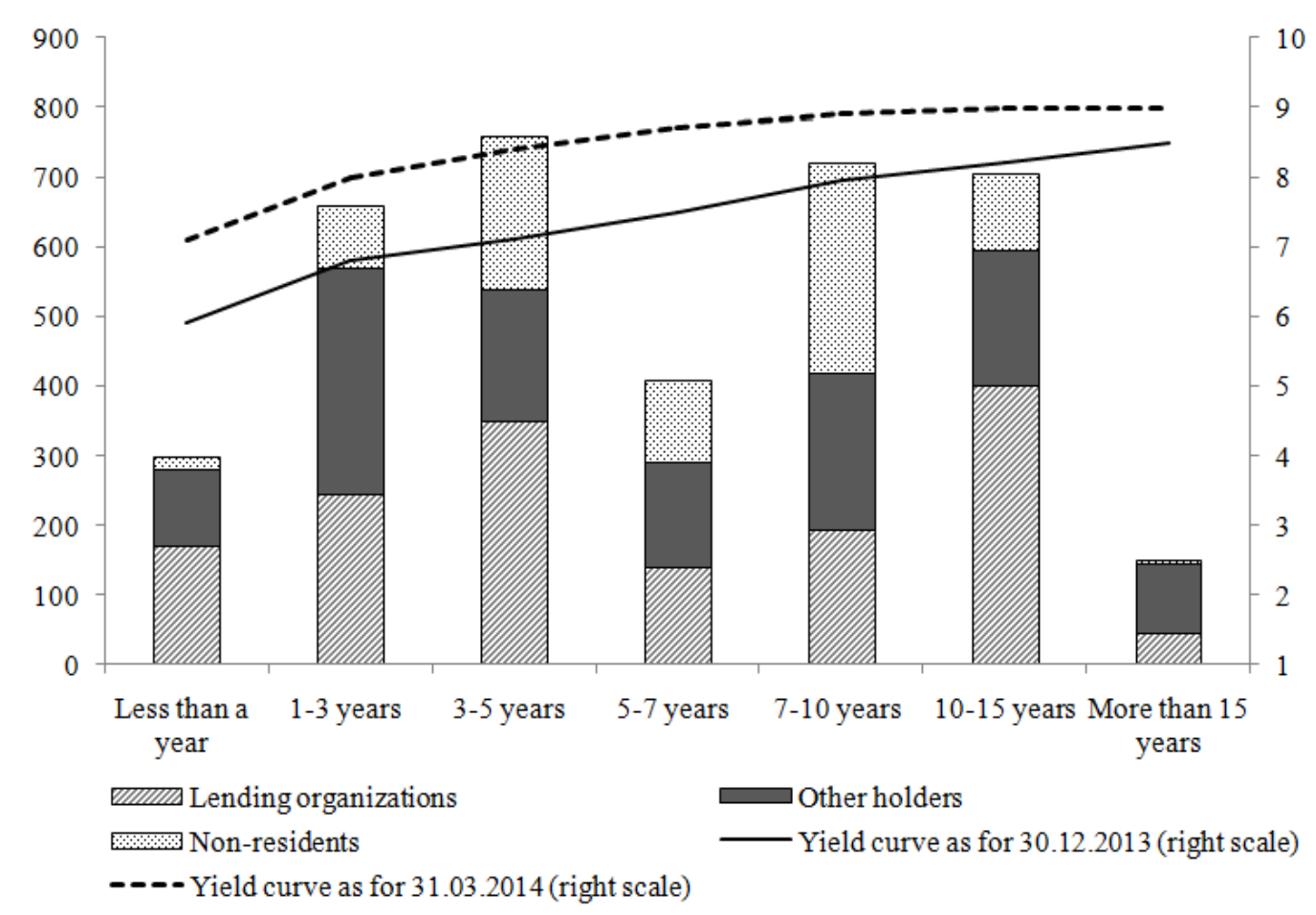

Fig. 4. Structure of federal loan bond holders regarding terms to maturity

Apparently, this figure is a result of a more attractive yield and lower sensitivity to interest rate risk demonstrated by short-term securities compared to the long-term (over 10 years) securities. Individual investors, investing in medium-term securities (3 to 5 years), can implement the strategy of holding bonds to maturity. In the short segment (less than a year) and very long-term segment (above 15 years) the investments by non-residents are minimal, which can be explained, respectively, by low yield and high sensitivity to the interest rate risk. From November 2013 we can see a downward trend regarding the presence of non-residents in the market of federal loan bonds. This is reflected in the reduction in the absolute volume of foreign investments in the federal loan bond market (from RUB 933 bln as for November 1, 2013 to RUB 836 bln by March 1, 2014), as well as the reduction of the nonresidents share in the total volume of the federal loan bond market (from 26 to $22 \%$, respectively). However, it should be noted that the decrease in investments had no considerable effect on the market; it happened quite gradually throughout the whole period and did not have a significant influence on the market performance. Today, it is not enough to simply return foreign players to the domestic bond market as they make serious demands for the infrastructure. Now, in order to perform operations with federal loan bonds, investors have to open a brokerage account in Russia, but this year it all may change when it may be allowed to trade federal loan bonds via Euroclear Bank SA, the world's largest accounting system for trading in bonds. Mexico and South Africa's bonds are already being traded in Euroclear. Euroclear will help to expand the range of investors in the federal loan bond market and reduce risks associated with Russia's infrastructure as well as make the federal loan bond market deeper and more liquid. In addition, this category of investors is more concerned with the country risks rather than domestic market players.

There is another important aspect that lies outside the possible influence from the Ministry of Finance - these are the market and market expectations themselves. Therefore, it is clear that the expectations of rates growth, increasing political and interest rate risks and permanently unstable market limit the non-residents' demand for long-term bonds.

Banking business is seriously exposed to the impact of external economic factors that affect the cost of funding in the banking sector and the level of liquidity in it. Due to this, interaction with various banking institutions in other countries increases the share of new operations, promotes the integration of banking capitals (national and foreign) and leads to unification of banking system models and standardization of banking supervision. The way of interaction between credit institutions and their customers also changes. The development of the branch network and long-term agreements are becoming less important: The main issue 
that matters now is new technologies that the Bank can use, i.e., remote access when performing standard banking transactions and operations.

Innovations in banking business can be brought in through new products and services, changes in maintenance, corporate organization and reporting standards.

Globalization of Russia's banking system is a notable trend of the modern development of the country. At any rate, banks should not be afraid of risks, but consider them as a way to make profit, an integral part of their performance which they can and should deal with. In the context of ongoing economic globalization, the reduction of risks in the banking sector can be carried out by means of changing institutional structure in this market segment, as well as improving legislative and legal foundations of the banking business. Insufficient data on diversification of banking risks in the process of globalization of the Russian economy and increasing relevancy of this issue determine the necessity of further research in this area.

The article justifies the authors' position as to the impact of financial globalization on banking risks and presents the mechanism of integrative motion of economic processes. The proposed methodological and practical solutions in the field of banking risk diversification in the context of globalization form the analytical basis helping to set the desired vector for further research to improve the effective adaptation of the Russian banking sector to the conditions of more stringent external and internal requirements, as well as contributing to the successful overcoming of the risk transformation process and new forms of risk manifestation.

\section{Discussion}

Improvement and development of the Russian banking sector are necessary not only for the internal modernization of the national economy, but also in the context of globalization, from the perspective of increasing competition in this business segment.

Global market imbalances have not disappeared from the world financial market. It has become much more difficult to identify and resist them. In addition to the adverse external factors, one of the main problems of the Russian banking sector is the increased concentration of risks. The article substantiates the authors' position in terms of the impact of financial globalization on the banking risks and presents the mechanism of integrative motion of economic processes in conjunction with the ongoing monetary policy of the country.

Russia's banking sector is one of the key segments of growth and capitalization of the entire domestic market, the stability and financial sustainability of the economy as a whole depending on this sector. Anyway, redistribution of cash flows and investments cannot be implemented bypassing the banking sector, therefore, diversifying banking risks in the current context of financial globalization seems to be one of the priorities of the study with the aim of successful practical implementation of the modern risk management techniques.

In the conditions of financial globalization, the banking sector is able to significantly increase the volumes of gross domestic product, conquer new economic niches and reveal their potential for innovation. This requires high-quality banking risk management mechanisms, contributing to the adaptation members to modern risks and self-protection of the industry in the event of the concentration of certain risks. Determining the risk degree, the ability to accept and effectively neutralize the increased risks of banking activity will determine competitiveness in the future.

Taking into consideration the abovementioned, it makes sense to discuss one type of banking riskscountry risk - in greater detail.

In international practice, a country risk is the risk of capital loss or the reduction of its value which is taken by foreign investors due to unstable economic or political market situation or due to other internal factors which have an impact on only one country. That is, this risk does not result from global processes.

The current situation in the Russian banking sector raises questions about transformation of the country risk. Withdrawal of banks' licenses due to their noncompliance with statutory ratios set by the regulator, as well as violation of banking legislation led to the situation when national players in the Russian banking sector, depositors whose deposits exceeded the amount guaranteed by the state, individual entrepreneurs and legal entities cannot invest abroad and have to passively store their capital in Russia, thus becoming exposed to the country risk.

This situation is not a typical one regarding the object-subjective understanding of the country risk. A system's exposure to "atypical" country risk or "inner" country risk is aggravated by its low predictability and the impossibility of hedging, thus, the following risk transformation is not subject to efficient management by the banking industry.

\section{Conclusion}

From the authors' perspective, right order of priorities in regulation and control by monetary authorities, consistency and validity of innovations as well as transparency of participants' activities should be seen as measures for minimizing exposure to this inner risk. Improving the quality and effectiveness of the risk management of the banking market participants including their exposure to "atypical" risks takes a new economic meaning in connection with the requirements 
of the Basel Committee to banks and especially to the capital adequacy. This is confirmed by the Russia's introduction from January 1, 2014 the standards set by Basel III (2012).

\section{Acknowledgment}

The authors express their sincere gratitude to Vyacheslav Zaborovskiy, Professor at the Department of Financial Markets and Insurance of the Ural Federal University (Yekaterinburg) for providing a representative sample of analytic data on the dynamics of correlation between the liquidity level in the Russian Federation banking system and the cost of funding, the structural liquidity deficit and the Bank of Russia's operations on liquidity support/absorption.

\section{Funding Information}

This research work was supported and funded by Gazprombank (Joint Stock Company), Yekaterinburg, Russia and also by Ural Federal University and Ural State Economic University.

\section{Author's Contributions}

Larisa Yuzvovich: Worked out the integration movement mechanism of economic processes with regard to the impact of financial globalization on the results of the monetary policy of countries.

Elena Knyazeva: Developed the concept of financial globalization and its impact on banking risks, advantages and disadvantages of financial globalization.

Natalia Mokeeva: Presented structural deficit of liquidity and the Bank of Russia operations on liquidity support/absorbtion.

Elena Avramenko: Studies the pool of external economic factors that affect the cost of the banking sector funding and the level of liquidity.

Maksim Maramygin: analyzed the level of liquidity in the banking system of the Russian Federation and the funding cost, as well the Federal Loan Obligations market in the context of maturity.

\section{Ethics}

This article is original and contains unpublished material. The corresponding author confirms that all of the other authors have read and approved the manuscript and there are no ethical issues involved.

\section{References}

Beloglazova, G.N. and L.P. Krolivetskaya, 2010. Banking industry. Arrangement of a commercial bank activity: Textbook. Yurait, Moscow.
Belyakov, A.V., 2004. Banking Risks: Problems of Accounting, Management and Controlling. 1st Edn., BDTs-Press, Moscow.

CPEBSBCLBR, 2003-2012. Core principles for effective banking supervision: Basel committee's letter on bank regulation. Business Law: Portal for Business Legal Support,

Dimitriadi, G.G., 2010. Risks in the Bank Management. 1st Edn., LKI, Moscow.

Granaturov, V.M., 2010. Economic risk: Essence, methods of measurement, ways for reducing. Delo i Service, Moscow.

Irishev, B.K., 2014. Crisis of Euro and global risks. Ves Mir, Moscow.

Keynes, J.M., 2012. General Theory of Employment, Interest Rate and Money. In: Transl, Lyubimov, N. (Ed.), Gelios-ARB, Moscow.

Krichevsky, M.L., 2013. Financial risks. KnoRus, Moscow.

Lavrushin, O.I., 2014. Banking business. KnoRus, Moscow.

Madera, A.G., 2014. Risks and chances. Uncertainty, forecasting and assessment. Krasand, Volgograd.

Molyneux, P., 2011. Bank performance, risk and firm financing. Palgrave Macmillan, UK.

Murphy, J.J., 2012. Intermarket Analysis: Principles of Financial Markets Interaction. 1st Edn., Alpina Publisher, Moscow.

Norman, P., 2013. The Risk Controllers: Central Counterparty Clearing in Globalized Financial Markets. 1st Edn., Mann, Ivanov and Ferber, Moscow.

Olsevich, Y.Y., 2014. Fundamental uncertainty of the market and financial theories. Aleteyya, Moscow.

Basel III., 2012. On the method of calculation of the amount and assessment of adequacy of the Net Worth (Capital) of lending organizations (Basel III): The Regulation of the Bank of Russia.

OMM, 2014. Overview of the money market for Q1 of 2014.

Rose, P.S., 1995. Bank management. Delo, Moscow.

Shapkin, A.S. and V.A. Shapkin, 2013. Economic and financial risks: Assessment, management, investment portfolio. Dashkov and Co., Moscow.

Sharpe, W.F., G.J. Alexander and J.W. Bailey, 2011. Investments. INFRA-M, Moscow.

Sheremet, A.D. and G.N. Shcherbakova, 2001. Financial analysis in the commercial bank. Financy i Statistika, Moscow.

Tepman, L.N. and N.D. Eriashvili, 2013. Banking risk management. Yuniti-Dana, Moscow.

Van Greuning, H. and S.B. Bratanovic, 2007. Analyzing banking risk: A Framework for Assessing Corporate Governance and Risk Management. Ves Mir, Moscow. 
Vishnyakov, Y.D. and N.N. Radaev, 2008. General Theory of Risks. Akademiya, Moscow.

Volkov, A.A., 2014. Risk management in the commercial bank: Practical guidance. Omega-L, Moscow.
Vine, S., 2013. Resource Optimization of the Modern Bank. 1st Edn., Alpina Publisher, Moscow.

Zharikov, V.V., M.V. Zharikova and A.I. Evseychev, 2009. Credit Risk Management. 1st Edn., TSTU Press, Tambov. 